\title{
Impact of the green revolution on the gender's role in wet rice farming: A case study in Karangwangi Village, Cianjur District, West Java, Indonesia
}

\author{
RUHYAT PARTASASMITA ${ }^{1, \boldsymbol{v}}$ BUDIAWATI S. ISKANDAR $^{2}$, SITI NURAENI ${ }^{3}$, JOHAN ISKANDAR $^{1}$ \\ ${ }^{1}$ Department of Biology, Faculty of Mathematics and Natural Sciences, Universitas Padjadjaran. Jl. Raya Bandung-Sumedang Km 21, Jatinangor, \\ Sumedang 45363, West Java, Indonesia. Tel./fax.: +62-22-7796412, `email: ruhyat.partasasmita@unpad.ac.id; rp2010rikkyo@gmail.com \\ ${ }^{2}$ Department of Anthropology, Faculty of Social and Political Science, Universitas Padjadjaran. Jatinangor, Sumedang, 45363, West Java, Indonesia \\ ${ }^{3}$ Undergraduate of Anthropology Program Study, Faculty of Social and Political Science, Universitas Padjadjaran. Jatinangor, Sumedang, 45363, West \\ Java, Indonesia
}

Manuscript received: 11 September 2018. Revision accepted: 2 December 2018.

\begin{abstract}
Partasasmita R, Iskandar BS, Nuraeni S, Iskandar J. 2019. Impact of the green revolution on the gender's role in wet rice farming: A case study in Karangwangi Village, Cianjur District, West Java, Indonesia. Biodiversitas 20: 23-36. The wet rice farming (sawah) is very complex that is determined by ecological and social economic and cultural factors, including soil conditions, water availability, weather and climate, population, local knowledge, beliefs, technology, and economy. In addition, wet rice farming is determined by the government policy and market economy. In the past, the Sundanese rural people of West Java practiced the wet rice farming based on the local knowledge or traditional ecological knowledge which is strongly embedded with local tradition, and division of labor based on the gender. Traditionally, most inputs of the wet rice farming, including rice seeds, organic fertilizer, and biopesticides were provided by internal resources of rural ecosystem. Both male and female farmers intensively involved in various $t$ wet rice farming activities based on the gender which is embedded by local tradition. For example, female farmers involved work in various activities that do not need energy but need to be careful and diligent, including the selection of rice seeds. Conversely, some works, including hoeing and plowing, were undertaken by male farmers. In the late 1960s, the Indonesian government modernized the wet rice farming through the Green Revolution program. Consequently, most rural farmers of West Java adopted this program. This research aimed to elucidate the impact of the Green Revolution program on the wet rice farming activities of Karangwangi village, Cianjur, West Java based on the gender issue. Aqualitative method with an ethnoecological approach was used in this study, while some techniques including observation, participant observation, and semi-structured interview were applied in this research. Thestudy result shows that in the past the wet rice cultivation of Karangwangi was traditionally carried out based on the local knowledge and embedded with local cultures, including traditional beliefs. Various activities of each stage of the wet rice farming were undertaken by male and female farmers based on gender and strongly embed by local tradition. By introduction of the Green Revolution, the female farmers have still involved in various activities of the wet rice farming. However, some female activities, including observation of star in the sky, rice seed selection, and ponding of rice grains of post-harvesting have been lost due to the introduction of the Green Revolution.
\end{abstract}

Keywords: cultivation activities, gender, Green Revolution, changes of wet rice farming system

\section{INTRODUCTION}

Management of agricultural activities in the agricultural system is very complex. Various agricultural systems, including wet rice farming (sawah) system has been determined by many factors, including local ecological, social economic and cultural, and the national and international policies (Iskandar and Iskandar 2011). Availability of local resources, including land, labor, and capital can strongly determine the agricultural productions (Mubyarto 1989; IFAD 2009; Herwantiyoko 1997).

The human capital of rural people, including local knowledge or traditional ecological knowledge and labor has been playing an essential role in agricultural production. The management of agricultural activities has been undertaken not only by male but also by female labor force. Division of labor of farming systems based on gender between male and female suggests that agricultural activities have been commonly undertaken by both men and women. In the farming system, the division of labor based on gender is very complex, including various works, different areas, different ethnic groups, and different classes in the community (Saptari and Holzner 1997).

Generally, the division of labor between male and female in the agricultural system has been identically divided, namely males involve in various works that need hard energy, including hoeing and plowing, while females involve in some tenacity and patience works, including seed selection. Therefore, the role of woman in agricultural management has been considered to be significant. However, agricultural research has given little attention to solving problems of female farmers and, in the design of new technologies, often disregards important questions of women's influence on decision making and labor allocation (Reijntjes et al. 1992).

Before introduction of the Green Revolution, namely to modernize the wet rice farming system in Indonesia, launched in the late $1960 \mathrm{~s}$, most works in the wet-rice 
farming system were undertaken by human labor and assistance of animals, including buffalo and cow power. Indeed, some women have intensively involved in various activities based on local knowledge and beliefs or cosmos. For example, in the past the planting of rice in the wet rice farming had to be undertaken by women because planting rice was considered to be appropriate conducted by women and the rural people belief on rice Goddess (Nyi Pohaci or Dewi Sri) (Iskandar and Iskandar 2011). Since the introduction of the Green Revolution along with the introduction of new rice varieties, inorganic fertilizers, and synthetic pesticides, hullers, and hand tractor, various works of male and female, particularly female, have dramatically changed. Consequently, employment opportunity for many rural women work in the wet rice farming have been lost (Saptari and Holzner 1997; LPTP 2010).

Modernization of the wet rice farming through the Green Revolution consisted of many programs, including meetings, discussions, and agricultural extensions on agricultural development have been emphasized on male farmers, but female farmers have been neglected. Therefore, various experiences and local knowledge of female farmers have dramatically eroded or have been lost (Simatauw 2001). There are some similarities and dissimilarities of experiences and local knowledge between male and female farmers. The understanding of gender and influence of value of local knowledge and skills is essential as specific local knowledge and expertise between male and female farmers on the wet rice farming system can be different. This has significantly affected access, utilization, control, and resulted in different perception and priority on using local knowledge and will have an influence on the next generation (Seleti and Tihompho 2014).

Based on tradition, subsistence farmers of West Java initially have practiced wet rice farming based on local knowledge and belief (Iskandar and Iskandar 2011). The female farmers have been intensively involved in almost every stage of the wet rice farming activities, including preparing seeds, crop maintenance, harvesting and postharvesting of rice. They have been able in keeping crop diversities using special local knowledge on local food for preserving the security of nutritional food of the community (Seleti and Tihompho 2014). Indeed, the local knowledge and experiences of female farmers have been important (Saptari and Holzner 1997). Accordingly, local knowledge and experiences of the female farmers on the wet rice farming have been considered to be essential to be studied

Some scholars undertook researches on the female farmers and division of labor in the agricultural sector. Among them, Atem (2018) studied the swidden (ladang) farming in Kalimantan and concluded that work activities of female farmers in the swidden farming of Sungai Kumpai, Kalimantan are higher than that of the male farmers. Similarly, Hutajulu (2015) also researched the role of the female farmer in the agricultural sector of Rasau Jaya Sub-district, West Kalimantan. Hutajulu (2015) found female farmers to actively involved in the management of agricultural economic household activities, including post harvesting. Further, Mahanani (2003), who studied the agrarian justice for women mentioned that agricultural mechanizations, mainly the rice threshing machine in Kubanga village, Banyumas, Central Java affected and replaced the women's role in rice processing in the wet rice farming system.

This paper elucidates the impact of the Green Revolution program on the gender's role in wet rice farming activities in Karangwangi Village, Cidaun Subdistrict, Cidaun District, West Java. Three aspects were elucidated in this paper namely agricultural calendar and agricultural activities, the gender's role in rice cultivation and various changes, and consequence of the Green Revolution.

\section{MATERIALS AND METHODS}

\section{Study site}

This research was conducted in Karangwangi village, and special hamlet, Puncakwangi hamlet was purposively chosen. Although most farmers in this hamlet have intensively adopted the Green Revolution since the end of the 1980s, some farmers have still practiced the traditional wet rice (sawah) farming. As a result, some local knowledge on the traditional management of female farmers has been maintained by farmers who have not adopted the Green Revolution. Administratively, Karangwangi village is one of the villages of Cidaun Subdistrict, Cianjur District, West Java Province (Figure 1).

Karangwangi village is located in border between Cianjur and Garut District. This village can be reached from the urban area of Bandung and Cianjur by using a vehicle in four main routes. Firstly, the passenger may travel from Badung to Ciwidey-Rancabali-NaringgulCidaun-Karangwangi that needs approximately 3 hours. Traveling through this route, the passenger can enjoy natural ecological landscapes, including forest and tea plantation, the main road is rather quiet but very steep slope. Secondly, the passenger may travel from Bandung to Karangwangi by using route Bandung-Garut-BungbulangRancabuaya-Karangwang, spending approximately 5 hours. Using this route, the passenger can enjoy the natural view of the south coast, and the main road is not steep. Thirdly, using the route of Bandung-Pangalengan-CisewuKarangwangi which needs approximately 2 hours and 45 minutes, the main road is steep. The fourth, the Karangwangi village can be achieved by using the route of Bandung-Cianjur town-Cilaku-Cibeber-CampakaPagelaran-Tanggeung-Cibinong-Sindangbarang-CidaunKarangwangi for more than 5 hours travel time.

Karangwangi village is located most east of Cidaun subdistrict, close to the south coast of Indian Ocean and directly border with nature reserve of Bojong Larang Jayanti. To the north, it borders with Cimarangang village. The village borders with the Indian Ocean to the south and Cidamar village, to the west, while to the east, it borders with Caringin village of Garut sub-district, separated by Cilaki river. 


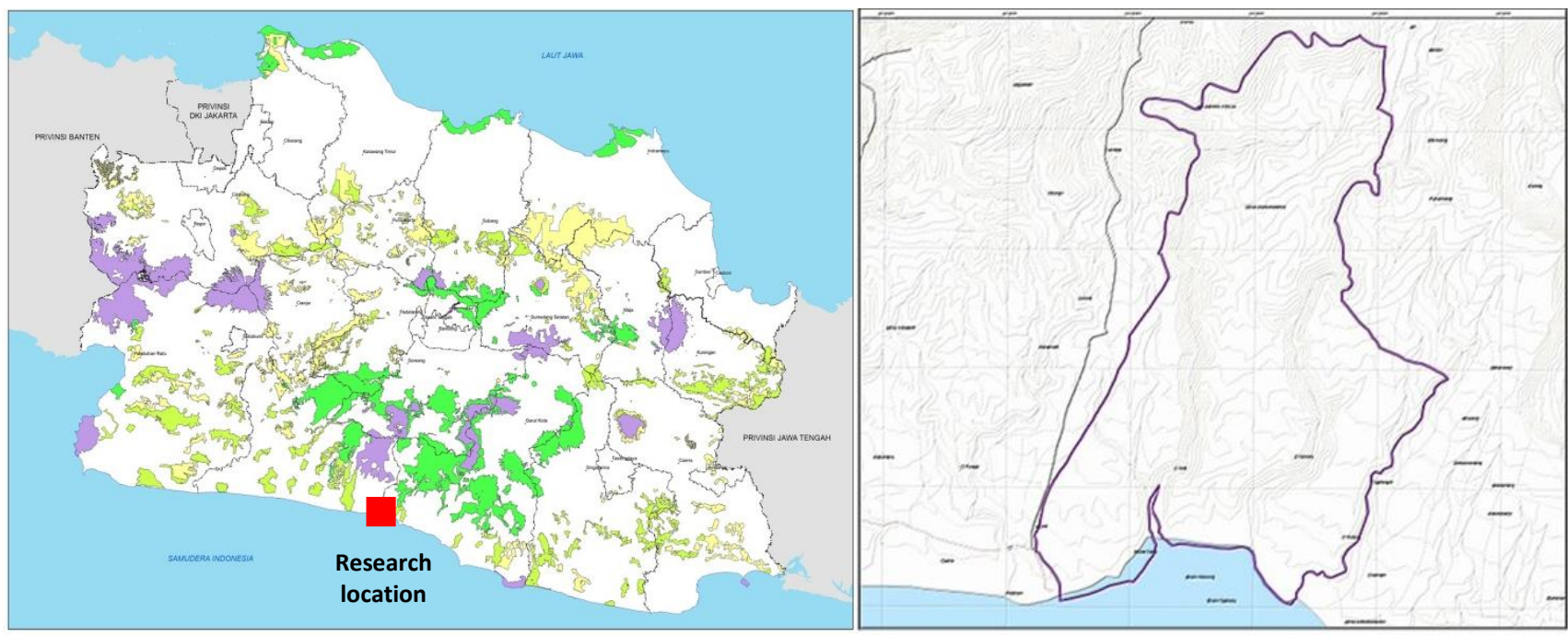

Figure 1. Research Location in Karangwangi Village, South Cianjur, West Java, Indonesia (Iskandar et al. 2016)

Table 1. Total agriculture area of Karangwangi village, Cidaun sub-district, Cianjur in 2018

\begin{tabular}{lll}
\hline Agricultural land use types & $\begin{array}{l}\text { Acreage } \\
\text { (ha) }\end{array}$ & $\begin{array}{l}\text { Percentage } \\
\text { of the total }\end{array}$ \\
\hline Wet rice field & & \\
$\quad$ Wet rice field, semi permanent-irrigation & 45 & 3.06 \\
$\quad$ Wet rice field, simple irrigation & 150 & 10.20 \\
$\quad$ Rainfed wet rice field & 760 & 51.67 \\
$\quad$ Tidal rice field & 12 & 0.81 \\
Dryland agriculture & & \\
$\quad$ Homegarden & 1,8 & 0.12 \\
$\quad$ Swidden & 450 & 30.60 \\
$\quad$ Dryland (tegalan) & 47 & 3.20 \\
$\quad$ People plantation & 5 & 0.34 \\
Total & $1,470.8$ & 100.00 \\
\hline Source: Village statisti
\end{tabular}

Source: Village statistic of Karangwangi village (2018)

Topographically, Karangwangi is situated in between $200 \mathrm{~m}$ and $275 \mathrm{~m}$ above sea level. This village has an average rainfall of approximately $3,500 \mathrm{~mm} / \mathrm{year}$, and average air temperature about $35^{\circ} \mathrm{C}$. Total area of Karangwangi villages was recorded 2,300.17 ha. The primary land use types consisted of the wet rice field and dryland (Table 1) (Karangwangi Village Statistic 2008).

Based on Table 1, wet rice field, particularly rainfed rice field was recorded the largest namely $51.67 \%$ of the total agricultural land. Meanwhile, the dryland agriculture was predominantly by swidden farming (ladang or huma) of approximately $30.60 \%$.

Regarding the wet rice field, almost every household of Karangwangi people's rice field (sawah). The dike of sawah has mainly planted by annual crops, including cowpea (Vigna unguiculata (L) Walp). During the dry season, the rainfed rice field has also commonly planted by annual non-rice crops (palawija), including pepper (Capsicum annuum L), peanut (Arachis hypogaea L), and cucumber (Cucumis sativus L). Most of the rice fields of
Karangwangi were recorded as rainfed. Consequently, water for cultivating rice has mainly obtained from the rain.

Meanwhile, some rice fields of Datarwangi hamlet have got limited water for cultivating rice, particularly during the rainy season from Cikawung River. Since the water availability is limiting, the wet rice fields only have one or twice per year. Generally, during the rainy season, the rice field is dominated by rice. After harvesting rice, the rice fields are mostly replanted by annual non-rice crops or has fallowed to wait for next main planting rice during the wet reason.

The dryland has been widely used for practice gardens and swidden (huma) farming. The garden may be divided into two types, namely it has been mostly annual crops which is called garden (kebun), and has been planted by dominant perennial crops, including fruits and woods which is called mixed garden or kebon tatangkalan or talun (the Sundanese last time term) (Iskandar and Iskandar 2011; Iskandar et al. 2016; Iskandar and Iskandar 2016a).

Like garden, the arable dryland that has been planted by rice is locally called swidden (huma) farming. Today, swidden farming (huma) have been opened from the garden or mixed garden instead of opening mature secondary forest (reuma) due to lack of the forests in Karangwangi village.

Another agricultural land use type is homegarden (pekarangan). The homegarden can be defined as land surrounding house planted with mixed annual and perennial crops. Because the traditional homegarden has been cultivated mostly by mixed-plant of annual and perennials, including fruits and woods, this traditional agriculture type has been categorized as traditional agroforestry (Iskandar and Iskandar 2011; Iskandar and Iskandar 2016b). Livestock such as chicken and sheep are also commonly integrated into the homegarden systems.

Most livelihoods of Karangwaing people were recorded as farmer and labor farmer. Other livelihoods of the people were also recoded as off-farm jobs, including as employee working outside of Karangwangi village (Table 2). 
Table 2. The livelihood of Karangwangi people in 2018

\begin{tabular}{lcc}
\hline Occupations & $\begin{array}{c}\text { Population } \\
\text { number } \\
\text { (persons) }\end{array}$ & $\begin{array}{c}\text { Percentage } \\
\text { of the total }\end{array}$ \\
\hline Civil servant (PNS) & 23 & 0.82 \\
Indonesian Police (POLRI) & 1 & 0.03 \\
Indonesian National Army (TNI) & 2 & 0.07 \\
Retired of POLRI/TNI & 3 & 0.10 \\
Private employees & 456 & 16,24 \\
Entrepreneur & 182 & 6.49 \\
Merchant & 110 & 3.92 \\
Farmer & 963 & 34.32 \\
Labor farmer & 930 & 33.13 \\
Fishermen & 117 & 4.17 \\
Services & 20 & 0.71 \\
Total & 2.807 & 100.00 \\
\hline Not Staticti
\end{tabular}

Note: Statistic of Karangwangi village (2018)

\section{Research procedures}

The research was carried out using a qualitative method with an ethnoecological approach (Creswell 1994; Martin 1995; Cotton 1996; Cunningham 2001; Spradley 2007; Iskandar 2018). Some techniques namely observation, participant observation, and semi-structured interview were applied to collect the primary data in the field.

The observation was undertaken to get general information of local environments, including settlement and home garden, garden, mixed-garden, and rice field. Participant observation was carried out by interviewing an active participant in some agricultural activities, including planting, maintenance, and harvesting rice to get more detail information of some agricultural activities. Also, some semi-structured interviews were done with competent informants, including informal leaders, formal leaders, female and male farmers that were purposively chosen. Household farmers were intentionally chosen to include women who serve the duties in the family as both husband and wife in managing the rice cultivation, and women who manage rice cultivation alone without their husbands who are going outside the village to involve in off-farm jobs in the urban area.

\section{Data analysis}

Data were analyzed by cross-checking, summarizing, synthesizing, and making narration. The data crosschecking process was undertaken by triangulating the information obtained from some informants, information collected from the interview, observation, and participant observation. The data also were validated with some reports, including village statistical data, and other research reports. Moreover, the data were summarized and synthesized, and the narration of descriptive analysis and evaluation was made.

\section{RESULTS AND DISCUSSION}

\section{Agricultural calendar and agricultural activities}

In the past, before the introduction of Green Revolution, each farmer household in Karangwangi village cultivated the wet rice field annually mainly based on the local knowledge and beliefs. According to Karangwangi people, the cultivation of wet rice farming has to be adapted with local weather and climate. The annual season (mangsa) can be divided into three main seasons, namely dry season (usum halo do), wet season (sum nigh or sum human), and transition season (usum pancaroba) from the dry season to wet season and vice versa.

Some natural indicators, including appearing of star constellation in the sky, falling leaves of certain plant species, the flowering of certain plant species, and animal behavior of certain animals have been used to know seasonal weather and climatic changes. It has also been used to decide appropriate season for the undertaking of each stage in the wet rice farming activities.

Particular star constellations, mainly binding kidding (the belt of Orion) have been widely used as an indicator of season changes. Based on informants, if the bintang kidang has appeared on the eastern horizon at dawn, it usually coincides with the dry season. The beginning of the dry season has commonly been indicated by a loud noise of insect of turaes (Cryptotympana acuta). Wild animal, mencek (Munticus muntjak) has also voiced in the night. In addition, at that time leaves of beurih (Aporosa frutescens Blume), randu (Ceiba petandra (L) Gaertn), dangdeur (Gossampynus heptaphylla Bakh), and pongporang (Oroxylum indicum Venth) have fallen. Usually, in the past, the dry season coincided with the sixth month (June) of BC calendar. Traditionally, cutting shrubs for land preparation of swidden farming, and land preparations, including hoeing or plowing in the rice field, have been undertaken in the sixth month. In the seventh (July) and eighth month (August), the bintang kidang has been seen higher in the sky. Moreover, approximately the tenth (October) and eleventh month (November), bintang kidang has usually been seen above the head or starting slightly to westward (bintang kidang luhur sirah jeung mengok/ngagilek ka barat), farmers had to plant rice in the swidden as well as wet rice field, as it is considered as the beginning of the rainy season (Iskandar and Iskandar 2016a; Iskandar et al. 2016). At that time, the leaves of randu and pongporang resprout, and tuber plants also report, has generally coincided with the tenth (October) and eleventh month (November). In the five months (May), Bintang kidang has not appeared any more on the western horizon at dawn, the planting of rice had to be stopped as that time has been considered not appropriate anymore because the soil is hot and a lot of pests, including kungkang (Leptocorisa acuta). Harvesting rice of swidden and wet rice farming has usually been undertaken in the third (March) and fourth month (April). Bintang kidang has not been seen in the sky in the fifth month for approximately 40 days. Later on, it can be seen again on the eastern horizon at dawn in the sixth month and coincide with the dry season, as an indication for preparing of land to cultivate rice. While the planting rice has usually undertaken in the tenth and eleventh month when the position of bintang are seen above the head.

Based on the agricultural calendar called pranata mangsa in Central Java (Wiramihardja 2013), in the past, 
planting and harvesting of rice both in the swidden (huma) and wet rice field (sawah) have been simultaneously undertaken by each household of Karangwangi people. The wet rice field can be divided into two types, mainly irrigated (sawah boyor) and rainfed wet rice field (sawah geludug or sawah tadah hujan). Unlike irrigated rice fields, rainfed rice fields are mostly planted by rice once during the dry season, and after harvesting rice, these crops are grown by annual non-rice crops (palawija) or planted. Unlike the irrigated rice field, the rainfed rice field has mostly planted by rice one time only during the dry season, and after harvesting rice, it has been planted by annual nonrice crops (palawija) or has been fallowed. Since the wet rice field has been simultaneously planted by the rural community, some pests, including brown hopper (Nilarvata lugens) has been avoided due to no food during the fallow time in the dry season.

\section{The cultivation of rice based on gender and various changes}

Based on the environmental history, the wet rice farming of Karangwangi village has been dramatically changed, mainly is caused by the introduction of the Indonesian Green Revolution initially launched in the late of 1960s, but it has been adopted by farmers of Karangawngi in two decades later at the end of 1980s.

The modernization of the wet rice farming through the Green Revolution program, the practicing of the wet rice farming in Karangwangi village has dramatically changed. In the following sub-sections, we elucidate the practice of wet rice cultivation and various changes in each stage of the rice cultivation, including preparation of rice seeds at home, land preparation for rice seedling, land preparation, planting, maintaining, harvesting, and post-harvesting of rice based on gender.

\section{Preparation of rice at home}

In the past, local rice seeds were obtained from the previous harvest. Traditionally, during harvesting rice, various rice varieties were carefully selected to be used for next year planting season. The rice seeds and its stalks were chosen which contain full and uniform grains. The harvested local rice seeds were commonly tied with bamboo rope becomes some bundles (gedengan). Moreover, the rice bundles (gedengan pare) were stored in a separate place at home instead of being stored in the rice barn (leuit pare). Rice seed borrowing among families was also very common in the past.

A few days before rice seeds were spread in the seedling nursery in the rice field, the rice seeds were soaked in a large basin (ngalemangkeun) to select good quality seeds. The good quality seeds were usually sunk, while poor seeds were floating in the water. The good rice seeds with its stalks were soaked in a fish pond (balong ikan) for one night. After two days immersed in a fish pond, the rice seeds were lifted and put it in the basin covered with a cloth for one night. On the chosen day as a good day, rice weeds are brought to and then spread in the nursery. Rice seed preparation is mostly carried out by female farmers. On the chosen day considered as a good day, the rice weeds were carried out to seedling nursery and later were spread out in the seedling nursery. Female farmers mostly undertook the preparation of rice seeds.

Unlike in the past, nowadays, after adopting the Green Revolution, the local rice varieties were replaced by new rice varieties or High Yielding Rice Varieties (HYVs). Today, the rice seeds are mostly bought from the shops. As a result, in each year rural farmers must buy rice from shops, and the rice seed preparation which was traditionally undertaken by female farmers in the past has not been practiced any more. One of the negative impacts of the Green Revolution program was the mass extinction of local rice varieties (Iskandar and Iskandar 2011; Iskandar et al. 2018).

\section{Land preparation for rice seedling}

From experience, along with the rice seed preparation at home, land preparation was also undertaken in the rice field. Firstly, the plot of the rice field located near the water inlet to the rice field (hulu wotan) was selected to make the rice seedling (nyieun pabinihan). Secondly, the selected rice field plot was hoed, flattened, and provided with water from a special water flow channel. Male farmer undertook the land preparation. When the land preparation was done, the rice seeds were spread (ditebar) by the female farmer. Each rice seed stalk was put on the ground which one of the tips of rice seed stalk was slightly pressured to avoid drifting away of water flow. The water control in the rice seedling nursery was undertaken by opening and closing the water channel that enters the rice field plot. Male and female farmers traditionally undertook the water control. In the past, various local rice varieties (landraces), including paré demol, jalén, sianghai, céré bokor, céré jamé, and pare benon were predominantly planted in the wet rice field. The rice seeds were allowed to grow in the rice seedling nursery for approximately between 20 and 25 days.

In the past, most local rice varieties were hairy and not easily fall out, which are known as pare ranggeuyan or pare gedengan or big rice (pare ageung), with the botanical name Oryza sativa var. javanica (Fox 1991). Today, however, the local rice varieties are not used anymore and already locally extinct. At present, the seedling nursery is made in the dryland (tegal) instead of in the wet rice field (sawah). The land preparation, the soil is hoed and flattened. After finishing the land preparation, rice seeds are spread. The rice seeds are mostly bought from shops instead of provided from the previous harvest. After spreading, the rice seeds are covered with ash and straws of alang-alang/eurih (Imperata cylindrical (L) Raeusch) or rice straws. If there is no rain, the rice nursery is irrigated by taking water from water sources, including river and pond.

The High Yielding Rice Variety widely cultivated in Karangwangi village is padi Ciherang. These rice seeds are allowed to grow in the seedling place (tempat pabinihan) for approximately 15 days. In the past, land preparations, including hoeing land was undertaken by male farmers. Today, land preparation for seedling plots in the dryland (tegal) is undertaken by both male and female farmers. 


\section{Land preparation in the wet rice field}

Before the Green Revolution, the land preparation of the wet rice field was undertaken by workforce and/or assisted by animal powers, including buffalo and cow. The land preparation was carried out in four stages. Firstly, the village irrigation channel (selokan) was prepared. For instance, the irrigation water dike was repaired by using soil, banana tree, and stones. As a result, if the rain comes, the irrigation water dike was not prepared any more, and water appropriate came in the rice field plots (petak sawah). Secondly, the rice field was roughly hoed by plowed of animal powers, including buffalo or cow. Thirdly, the grasses grow in the rice field were cleared by using a hoe (namping), and and the patches of rice fields (galengan) was repaired and reinforced by wet soil (mopok galeng). Fourthly, the second hoeing was undertaken to more smooths the soil which is locally called ngangler. This work was also commonly done with the assistance of animal powers, including buffalo or cow. Fifthly, the land was flatted by a wooden slab (ngarata) as the hoed soil (singkalan) is still undulating or not flat. The flatting was done using a wooden plate with a T-shape wooden handle. A man usually evicted the wooden slab. Thus, all activities of land preparation were done by male farmer.

Nowadays, after the Green Revolution activities of land preparation have been mechanically done. Most of the workforce as well as the animal power for land preparation have been replaced by hand tractor which is locally called seki. Also, before planting rice, the land has been lined by using a special tool made of wood with similar shape as a wood comb (caplakan). The caplakan has been usually evicted by men made lines on soil with the distance between one to other lines of approximately $20 \mathrm{~cm}$. Some positive aspects of using hand tractors, among others, is the land preparations are quickly undertaken. While using caplakan, the planting of rice has been easily done by women. However, by using a tractor, fossil energy is intensively used. Also, since only wealthy farmers have owned the hand tractor, introducing the hand tractors in the rural subsistence area has dramatically created the low equitability of the production system of the sawah agroecosystem (Conway 1986). Today, most farmers have mostly rented the hand tractor from the wealthy farmers who owned hand tractor. Besides, the use of animal powers, including buffalo and cow have been replaced by tractors. Consequently, the populations of both buffalo and cow have dramatically decreased or have been extinct. Today, all activities of land preparation mainly have been undertaken by male farmers.

\section{Planting}

In the past, one day before planting, a special traditional ritual was undertaken. To perform the traditional ritual, pupuhan was made. The pupuhunan was used as an indication that the landowner would plant rice in the wet rice field. The pupuhunan consists of various plants mainly hanjuang (Cordyline fruticosa (L) A. Chev), bingbin (Pinanga sp), seel (Daemonorops melanochaetes Blume), bamboo (Gigantochloa apus (JA \& J.H Schultes) Kurz) was filled with water, and incense. The ritual was begun by burning incense (parukuyan), and prayer was undertaken by a man of each head of household. However, if a household man was not able to perform the ritual, he asked an expert of the performing ritual who is called as buhun to complete the task. The ritual was undertaken in the hulu wotan that is the border between the rice field plot and inlet of the first water come in from irrigation water channel or river, traditionally considered as neutral location. The primary purpose of praying was to get a blessing (selamat) for planting rice.

Moreover, on the day of planting the rice, rice seeds were removed from the seedling nursery (babut). The rice seedlings were bundled by tying using a bamboo rope. The tips of rice seedling were cut by a knife to get uniform height of the rice, and the seedling leaf tips would not touch the ground if the rice grows high. Men carried the bundled seedling rice to each plot of the rice field. To easily get saddling bundles for women who were going to plant rice, each saddling bundle was thrown to each rice field plot. The rice bundle was opened and the seedling rice was individually taken for planting. The planting of rice was called tandur, meaning tanam padi mundur or 'planting rice by backward'. Planting rice was undertaken by women. It was traditionally considered as appropriately undertaken by women due to hand of women as perceived not hot and appropriate for the rice goddess (Nyi Pohaci or Dewi Sri) (Iskandar and Iskandar 2011).

Today, after the Green Revolution, the traditional ritual in the special place of the puuhunan is not undertaken any more. Making the lines on the ground before planting rice has mainly undertaken by men. In addition, the planting of rice is undertaken by women not only by moving back ward but also moving forward due to the availability of lines on the ground made of caplakan that can assist them to grow each rice seeds (Figure 2)

\section{Maintenance of rice}

The weeding of aquatic weeds is one of the main activities of maintenance of rice crops in the wet rice field. The weeding (ngarmbet) was undertaken between two or three times in a growing season. The first weeding, the second weeding, and the third weeding were locally called ngarambet munggaran, ngarambet mindo, and ngarambas, respectively. The first weeding was undertaken between fifteen and twenty days after planting the rice. The second weeding was carried out approximately one month after planting. The third weeding was only undertaken if the weeds do grow again in the rice field. The weeding was undertaken by female farmers.

Other activities of rice crop maintenance activities were water control and pest management. The water control was aimed to provide water supply in the rice field plots. If the rice field experiences water shortage, the irrigation is provided from the water channel. Conversely, if too excessive water is available in the rice field, some of the water was removed from the rice field plots. Male farmers undertook the water control. 


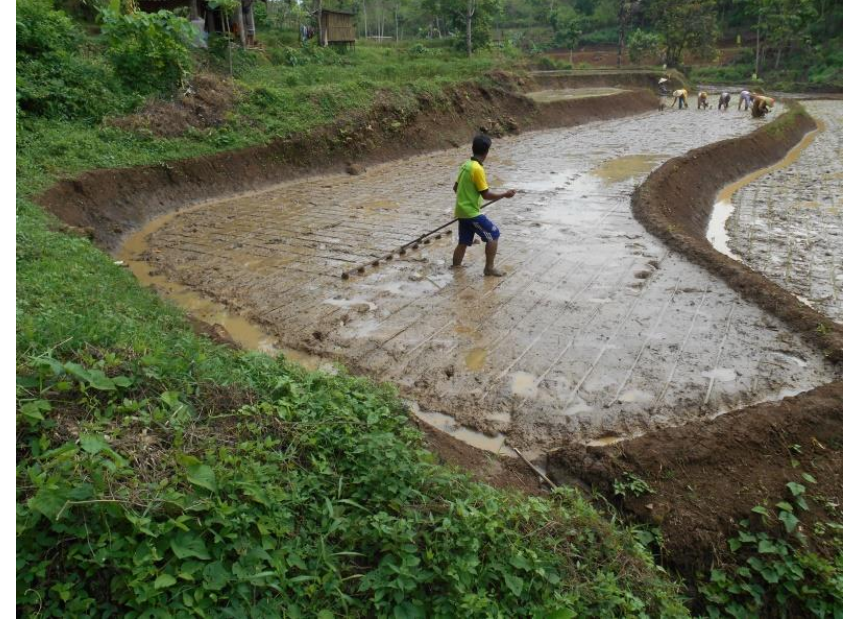

Figure 2. A male farmer is making lines by using a wood comb (caplak) in the rice field that is going to be planted with rice

Traditionally, rice pest was driven away by some ways, including making scarecrow (bebegig), and cans were hung to the rope (kokomprang) and pulled by people who are waiting in a farm shelter (saung). Another technique was by using used clothes dipped in human urine (pepecing), which smell will prevent the pests attack the rice fields. Pest control is also carried out by hanging clothes using a cloth hanger tied to the tip of a bamboo pole (kohkol péténg), which then produces sounds during a breeze that cause the pest to go away from the rice field. Moreover, pest control is also carried out by using some vegetable pesticides or biopesticide from plants such as Cassumunar ginger/panglay (Zingiber cassumunar Roxb), and garlic (Allium sativum L). Also, incense was burned to produce strong scent as a repellant. In other words, the pests were repelled by biopesticide instead of killing (Reijntjes et al. 1992). Indeed, it was considered as ecologically sound as it did not kill animal pests and did not produce pollution to the environment. Some pests of rice crops, mainly kungkang, burung pipit (Lonchura leucogastroides) and jodog/babi hutan (Sus vittatus), and brown hopper (Nilaparpata lugens) were not recorded in the past. Male farmers usually made the pest controls.

After the Green Revolution program had been adopted, today the weeding is done by herbicide spray which is locally called obat ali. Male farmers undertake the control of weeds using herbicides. Although herbicides have been applied, the manual weeding must be undertaken by male farmers using a wood and nailed of nails (gasrokan or lalandak) as the grass weed jajagoan (Echinochloa sp) has not been able to be killed by herbicides. In addition, synthetic fertilizers were intensively provided, and pest spraying is carried out by male farmers using synthetic pesticides (Figure 3). However, some tools of pest repelling have been also still applied by the community. Today, some pests mostly recorded are burung pipit (Lonchura leucogastroides), wereng (Nilaparvata lugens), kungkang (Leptocorisa acuta), lembing batu (Scotinophara coarctata), jodog (Sus vittatus), gaang (Grillotalpa africana), and hama bodas (Nymphula depunctalis). While,

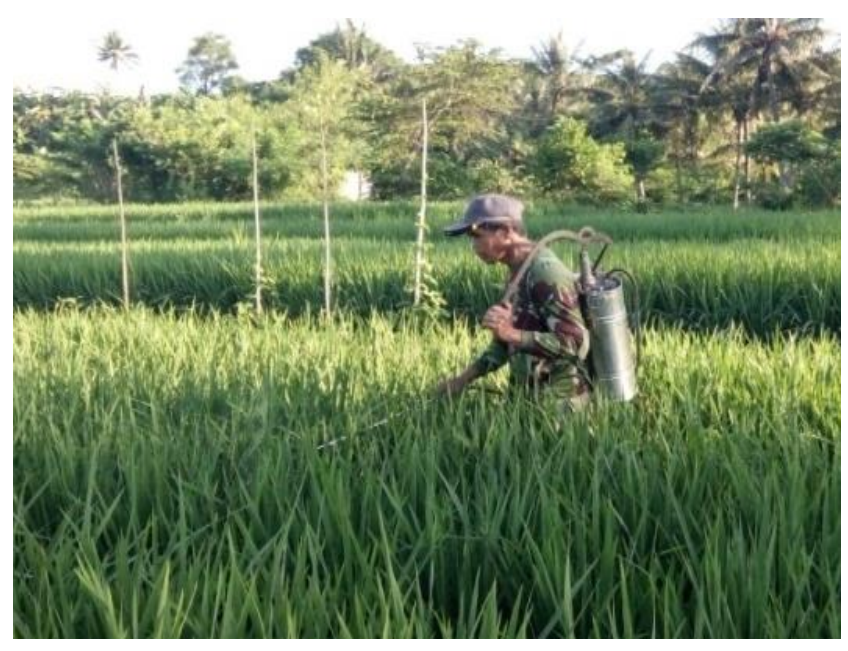

Figure 3. Rice is being sprayed by male farmer

the grasses as weeds are mainly rumput jampang piit (Digitaria cliaris (Retz) Koeler), genjer (Limnocharis flava (L) Buchenau), eceng (Eichhornia vaginalis), kamanilan (Nasturtium indicum L), cacabean (Ludwiga octovalvis (Jacq) P.H. Raven), jajagoan (Echinochloa sp), and jajaruman (Andropogon aciculatus Retz).

\section{Harvesting rice}

Traditionally, in the past the day before harvesting rice, the rural farmer prepared pupuhunan to conduct traditional ritual. The pupuhunan was put on the place of hulu wotan. In addition, rarangkén was preferred consisting of midrib and young leaves of kawung (Arenga pinnata), a wooden stick of sulangkar (Leea indica (Burm.f) Merr), leave of pacing (Costus speciosus), and hoar were collected, arranged and put on the place of pupuhunan. Processing of rarangken was undertaken as following. Firstly, a wooden stick of sulangkar (Leea indica (Burm.f) Merr) was plugged on the ground. On top of a wooden stick of sulangkar was midrib of kawung (Arenga pinnata Merr) which is rounded up. Moreover, leaves of kawung were separated from its midrib. As a result, the stick of kawung midrib lead up, and its sticks were tied with cone-shaped boiled rice (congcot) and kawung leaves dangling down. Various plant leaves including seel and pacing (Costus speciosus (J. Coenig) Sm) were hung on kawung leaves. Some traditional cakes made of rice, including tangtang angin, kupat, leupeut, peuyeum, and tumpeng rice and its side dishes were put in a wooden small house box (sanggar). Afterward, sawen made of the young leaf of kawung/Arenga, pacing, and sulangkar were placed on the right and left of the foot path to the wet rice field. The purpose of this offering on pupuhunan is to get permission from spirit of ancestor (karuhun) and the spirit of rice for harvesting rice, which is commonly expressed by farmers as 'mipit amit, ngala menta' (picking must be permission), and the expression gratitude for has succeeded in plating rice and sharing food. This performing ritual before harvesting rice was very commonly undertaken by rural farmers in West Java and Banten or everywhere in rural 
areas of Indonesia, as an expression of traditional beliefs regarding the spirit of rice (Iskandar 1998; Dove 2005; Iskandar and Iskandar 2011; Iskandar and Iskandar 2017). Socially, it has been considered that belief system serve a variety of adaptation of human societies to their environment and their member of rural community. Culturally, a shared pattern of beliefs can often provide a strong sense of group solidarity that unifies different individuals or diverse backgrounds, ages, and/or socioeconomic interests into a larger and more cohesive unit (Lovelace 1984).

On the day of rice harvesting (dibuat or panen pare), the rice was harvested in several stages. Firstly, the rice panicles were cut of using a small knife (etem or ani-ani). Secondly, each bundle panicles was tied with a bamboo rope; each bundle was called eundan. At the same time, a good quality seed of each rice variety was selectively harvested. Harvesting of rice was undertaken by female and male farmers. Thirdly, all rice bundles were hung along bamboo pole and then dried under sunlight. The hunging of rice on a long bamboo was called nyalai or ngalantarayan pare. Fourthly, one bundle of dry rice was mixed with another bundle tied with bamboo rope, which is called mangkek. One rice bundle was called one eundan, and combination of two eundan that is tied by bamboo rope is called one gedeng. Drying (nyali) and tying dry rice bundle (mangkek) were under taken by male farmers. In addition, the rice seed panicles were tied of making several bundles that are called making the mother and the father of the rice (ibu rama pare). Several rice seed bundles symbolize the 'rukun islam' and 'number of prey rakaat.' Fifthly, the rice bundles were hung on a bamboo pole that is shouldered by a male farmer and carried from the rice field to rice barns (leuit) in settlement or hamlet (kampung). Traditionally, some of the bundles of dry rice carried using a bamboo pole by a male transported from the rice fields to the rice barn, with rice bundles swaying create a distinctive sound. The sound was caused by the friction between bamboo straps and bamboo stems, called ngarengkong. Men undertook the carrying of the dry rice and ngarengkong.

Since most farmers have adopted the modernization of wet rice farming through the Green Revolution programs, including planting high yielding rice varieties (HYVs), the harvesting of rice has dramatically changed. For example, some activities including making pupuhunan, rarangkén, and sawén have no longer been practiced. In addition, harvesting rice is predominantly done by using a sickle (arit or sabit) instead of using a small knife (etem) and mostly undertaken by male farmers and assisted by female farmers (Figure 4). Therefore, unlike in the past, today's rice harvesting has mainly undertaken by male farmers. After all the rice stalks are cut with a sickle, all stalks are transported and collected, conducted by male farmers (Table 5). Moreover, unlike in the past, today, the rice and its stalks are beaten by using a wood so that the rice fall out (Figure 6), and then the leaves and dirt mixed with rice are degraded, and spread on a traditional bamboo mat (giribig) or plastic mat (terpal) and dried under sunlight (Figure 6). Later on, rice grains are selected assisted by wind gusts (ngagelebeg), and it can be put in a plastic sack, undertaken by a female farmer (Figure 8).

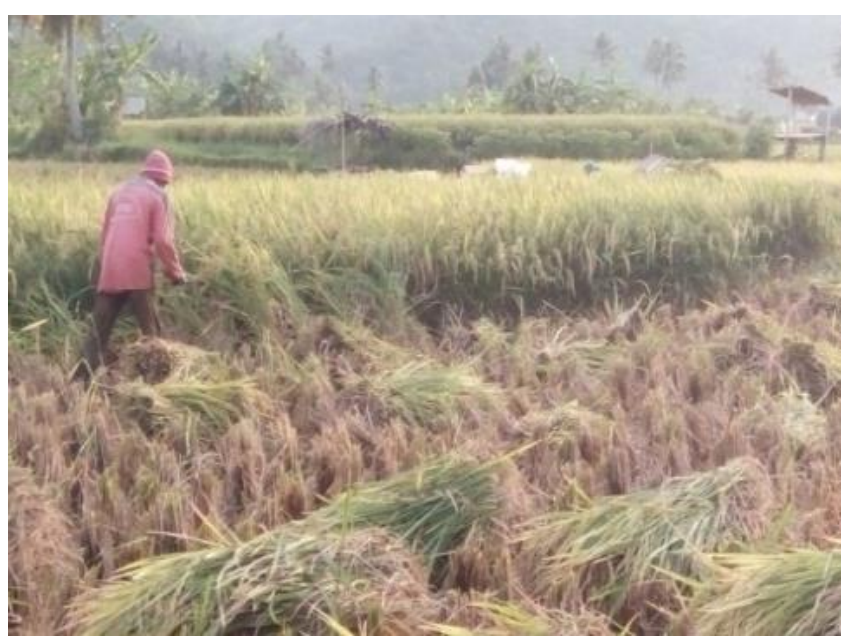

Figure 4. Rice is being harvested by using sickles undertaken by male farmers

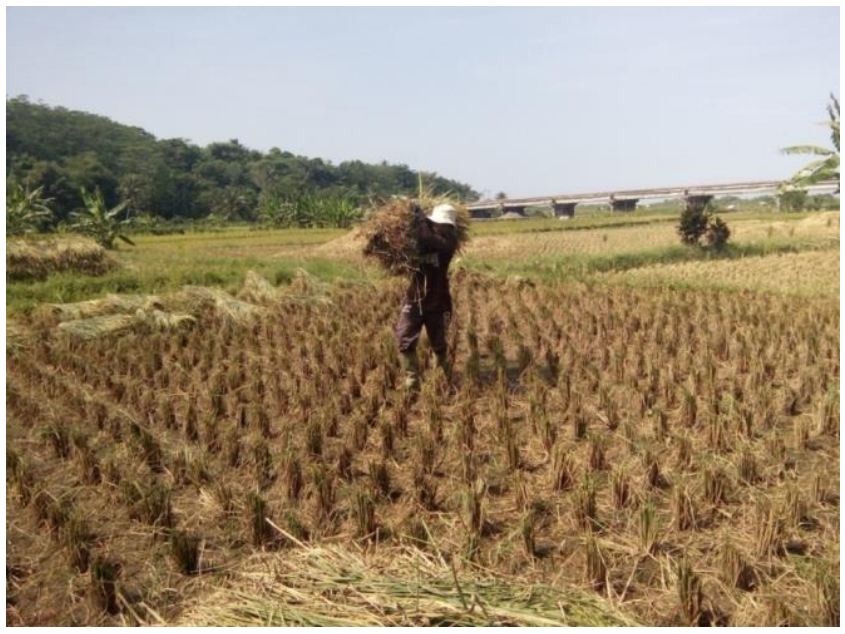

Figure 5. Rice and straw are being carried by a man from the rice field

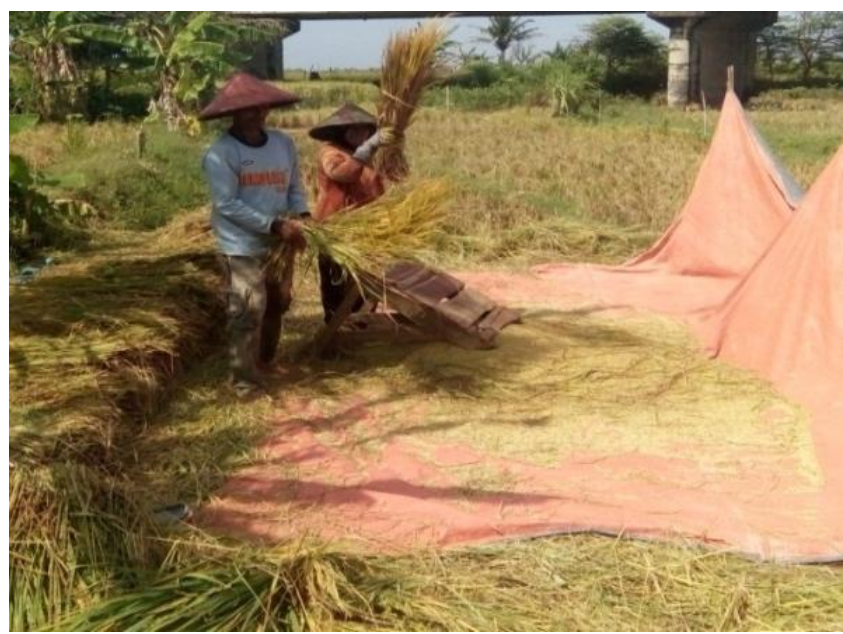

Figure 6. Rice is being hit by a male and female farmer to fall out rice grain 


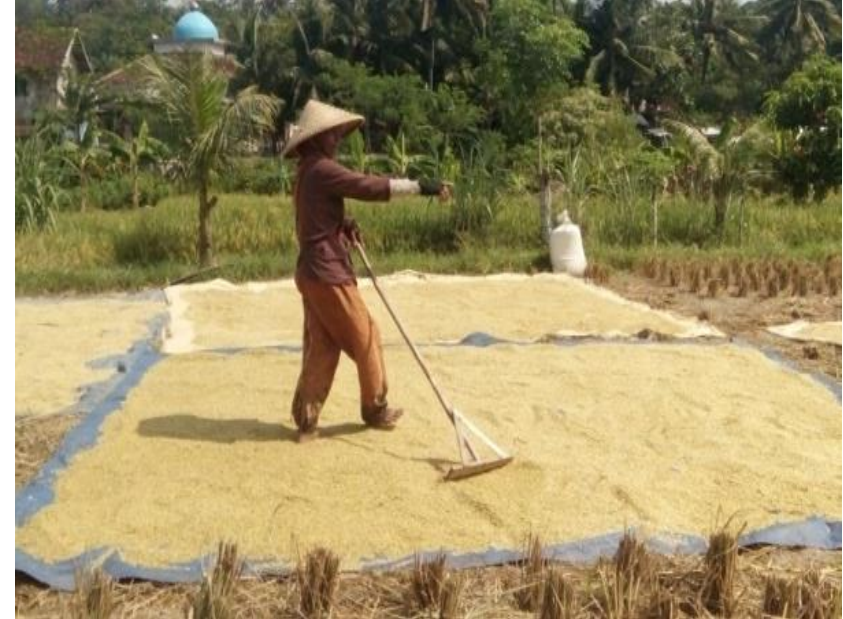

Figure 7. Female farmer is drying the harvested rice on a bamboo mat (giribig)

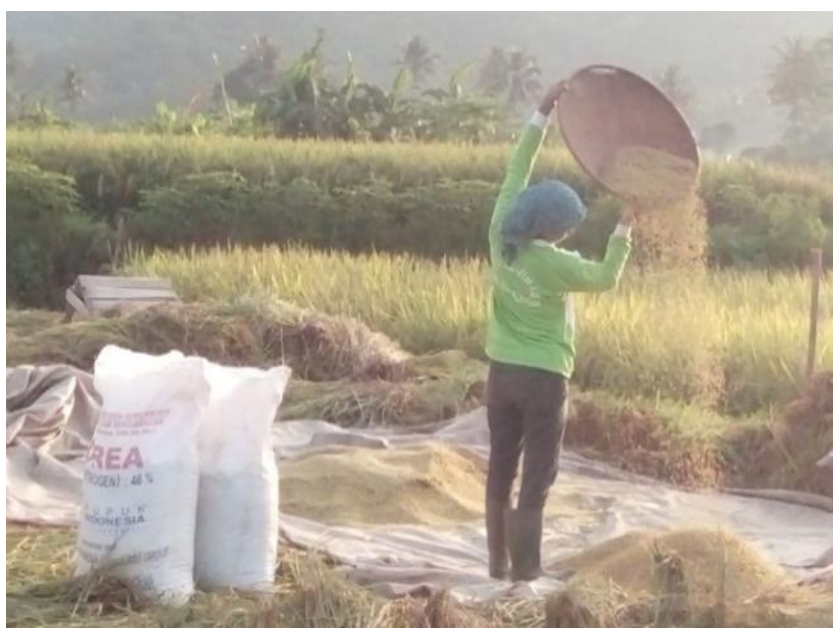

Figure 8. Rice grains are being selected and assisted wind gusts (ngagelebeg) undertaken by a female farmer

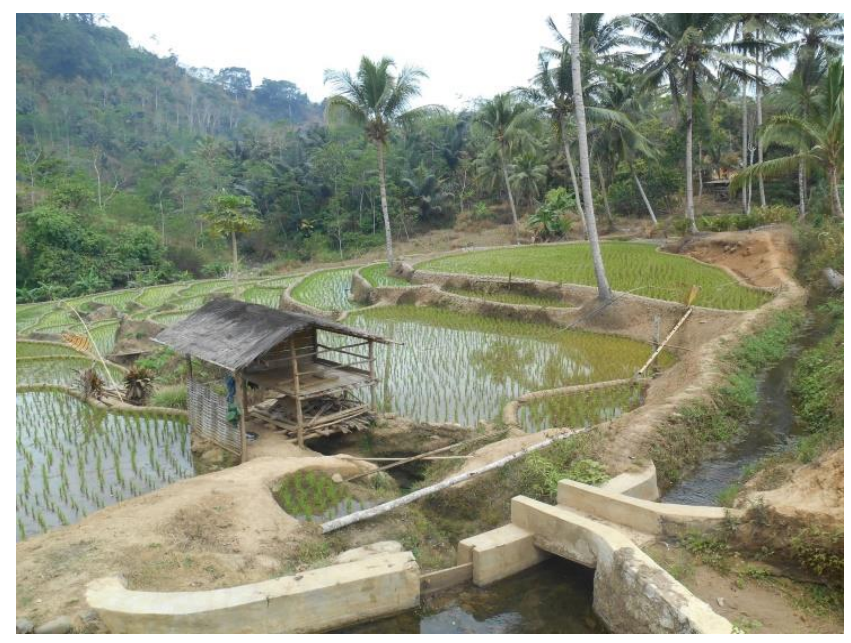

Figure 9. The simple rural irrigation system of the Karangwangi village, South Cianjur, Indonesia
Today, rice panicles are not dried any longer on bamboo (nyali) as the High Yielding Rice Varieties (HYVs) is known to fall off easily and cannot be bundled and tied with bamboo rope. Besides, since the rice seeds have been put in a plastic sack, the rice barns (leuit) are lost. According to some informants, the rice barns have disappeared approximately at the end of 1980s along with the introduction of the Green Revolution.

\section{Post-harvesting}

In the past, after the rice harvest, the rice fields (sawah) were not immediately re-cultivated because the rice field was cultivated only once in a year during the wet season. Traditionally, after harvesting rice, the rice field that has a lot of water (sawah boyor), fresh water fishes were raised and mixed with genjer (Limnocharis flava (L) Buchenau) as a traditional vegetable plot. The wet rice field of rainfed (sawah geledug), however, was allowed to fallow during the dry season. The rice bundles (pocong or gedeng pare) were put in the rice barn and prohibited to be sold. But some non-rice crops, including peanut (Arachys hipogaea L) was allowed to be sold for cash. For daily food consumption in the household, the rice bundles were taken by the female from the rice barn and were pounded in the wood mortar in a rice pounding shelter (saung lisung). The hulled rice (beas) was put in a boboko (woven bamboo basket) and washed in water (ngisikan). Moreover, it was steamed in a metal vessel (seeng) and fire woods were used to cook rice. The cooked rice was mostly consumed two times or sometimes three times per day, mainly early morning and the afternoon or sometime in the midday by consuming the rest cooked rice of the morning (cf. Igarashi 1985).

In the recent development, the wet rice field has been cultivated primarily twice each year, because High Yielding Rice Varieties (HYV) are mostly short duration about 100 days and rural water irrigation has been improved (Figure 9). Since the rice field has been cultivated two times or continuously grown by rice through the year without fallowed time, various activities including observation of the kidang for deciding appropriate time of land preparation and planting rice have not been practiced any longer. Consequently, the planting time and harvesting of rice have not been simultaneously undertaken. Indeed, the pest outbreak and lack of water in the dry season have frequently occurred in the intensive wet rice farming (cf. Lansing 1991; Fox 1991; Iskandar 2014; Winarto 2016).

One of the differences practice of wet rice farming in the past and that at present time is that in the past, the practice of wet rice farming was based on not only economic practice but also it was strongly embedded by cultural aspects, including belief systems serving a variety of adaptive functions for human societies and their members (Lovelace 1984; Iskandar and Iskandar 2011). Nowadays, some mechanizations of the wet rice cultivation have mainly applied in wet rice farming. After harvesting rice, rice straws are burned (Figure 10), and if the water availability is considered to be appropriate, the land is hoed or processed by hand tractor to be replanted with rice. 
However, if the water is insufficient, the wet rice fields are commercially planted with non-rice crops, including chili (Solanum annuum L). Before planting the non-rice crops, the soil is dried (Figure 11) and then hoed, and planted with commercial crops, including chili.

\section{The consequence of the Green Revolution}

Based on the case study in Karangwangi village, it was revealed that in the past, before the Green Revolution program was introduced, the rural people of Karangwangi managed the wet rice farming based on the local knowledge or traditional knowledge transferred from their ancestor and their experiences in intensive interaction with their local environment in the management the wet rice cultivation.

In the past, the rural people of Karangwangi annually cultivated the wet rice farming that has been adapted with environmental factors, including weather and climate. Therefore, culturally, before starting the cultivation of wet rice farming, the farmers must carefully observe appropriate season to decide appropriate time to conduct land preparation and planting of rice. The constellation of the belt of Orion (bintang kidang or bintang wuluku) was mainly used as indicator to choose an appropriate time to conduct each stage of wet rice farming. The annual appearing of bintang kidang on the eastern horizon at dawn usually coincides with the dry season, at that time rural people prepared land for planting rice. Moreover, when bintang kidang appeared above the head or slightly inclined to the west, it usually coincides with the start of the wet season whenthe rural people started planting the rice. When bintang kidang could not be seen anymore in the western horizon, the planting time had to be stopped because the time is considered not appropriate for planting rice. After harvesting rice, rural people recultivated the wet rice field or fallowed it depends on the water availability. By using bintang kidang as an indicator for starting and stopping the rice planting, the planting and harvesting of rice were simultaneously undertaken at the same time. As a result, the pest control and irrigation were properly managed (Lansing 1991; Iskandar 2017).

In the past, each stage of the wet rice cultivation was undertaken by farmers based on gender and embedded by local culture. For example, the selection of rice seeds, planting and harvesting, and post harvesting of rice were traditionally undertaken by famale farmers. Male farmers commonly conduct the hoeing and plowing.

At the end of 1980s, the Karangwangi people adopted the Green Revolution introduced through the government policy. The modernization of the wet rice farming has dramatically changed the wet rice farming. Although the Green Revolution has a positive impact, including the increase of rice production, some negative consequences of this program have also occurred (Table 3).

For example, the planting and harvesting of rice have not been simultaneously undertaken by all rural community. Planting rice has been continuously undertaken throughout the year without using various natural indicators for deciding the appropriate time for multiple activities of wet rice cultivation. In addition, various internal inputs such as local rice varieties, organic fertilizers, and organic biopesticides have been replaced by external inputs such as High Yielding Rice Varieties (HYVs), inorganic fertilizers, and synthetic pesticides. The hand tractor and huller has been also introduced. The introduction of new rice varieties, hand tractor, and huller has caused dramatic changes of the division of labor based on gender. For example, rice seed selection and preparation traditionally undertaken by female farmers were not practiced any longer as the local seeds were replaced with HYVs that are usually bought from the market. The traditional pounding of rice by using wood mortar that was traditionally undertaken by female farmers and the vital role for sharing income by providing labor of poor women had disappeared due to the introduction of the huller. Also, women labors role in harvesting to provide shared income for rural poor women have dramatically reduced or been lost due to the introduction of HYVs, and the rice harvesting has predominantly undertaken by using sickles, mainly conducted by male farmers.

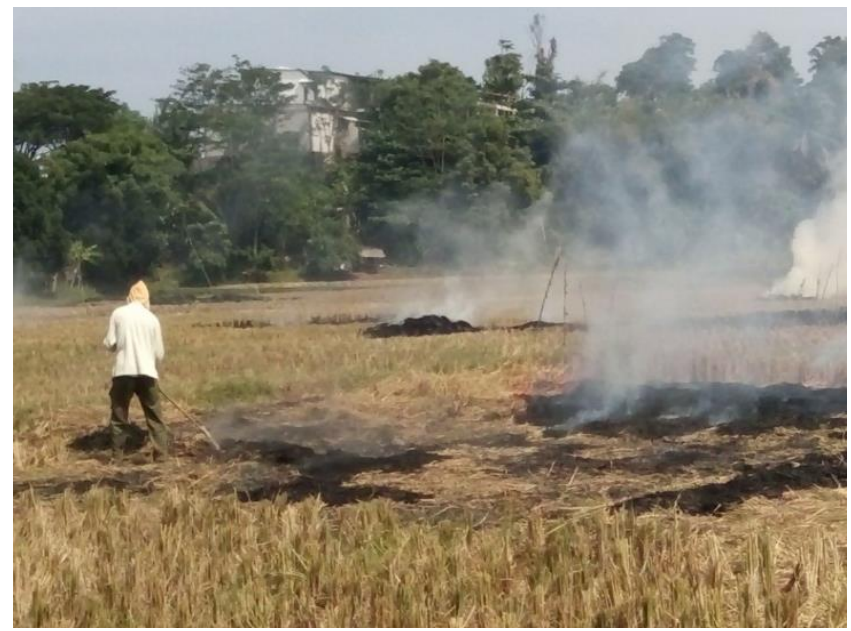

Figure 10. Rice straws are being collected to be a mound and burned undertaken by a male farmer

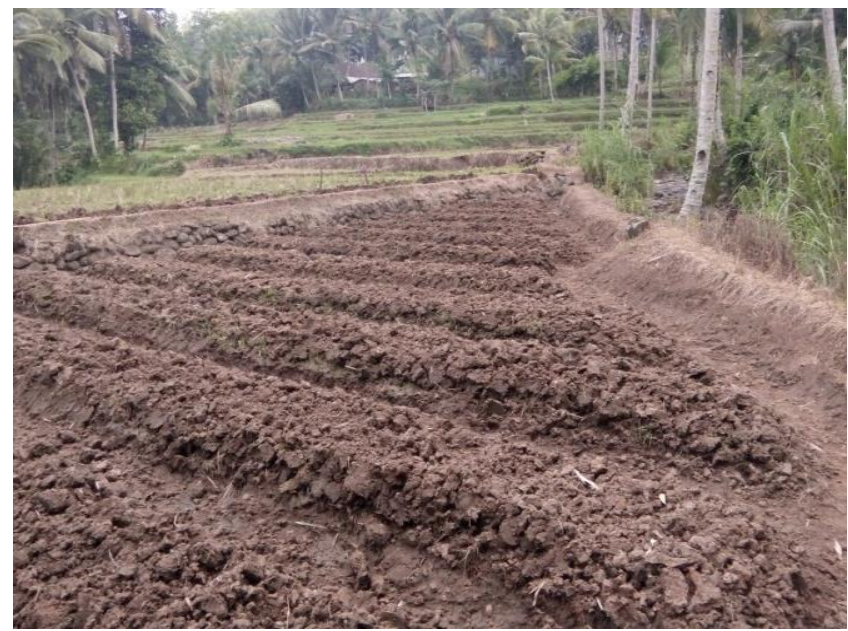

Figure 11. The hoed soil is being dried to be planted with seasonal non-rice crops (palawija) 
Table 3. The changes of management activities in the wet rice farming after the green revolution and its consequences in Karangwangi village, Cianjur, West Java, Indonesia

\begin{tabular}{|c|c|c|c|c|c|c|}
\hline \multirow[b]{2}{*}{ Phase } & \multirow[b]{2}{*}{ Activities } & \multicolumn{3}{|c|}{ Before the green revolution } & \multirow[b]{2}{*}{ Present time } & \multirow[b]{2}{*}{ Consequences } \\
\hline & & Tool used & $\begin{array}{c}\text { Done } \\
\text { by } \\
\text { male }\end{array}$ & $\begin{array}{c}\text { Done } \\
\text { by } \\
\text { female }\end{array}$ & & \\
\hline \multirow{4}{*}{$\begin{array}{l}\text { Seed } \\
\text { preparations } \\
\text { at home }\end{array}$} & Observation of sky & No tools & Yes & Yes & No longer practiced & $\begin{array}{l}\text { Loss of local knowledge on } \\
\text { weather and climatic conditions }\end{array}$ \\
\hline & $\begin{array}{l}\text { Rice seed selection } \\
\text { and seed } \\
\text { preparation }\end{array}$ & Large basin & No & Yes & No longer practiced & $\begin{array}{l}\text { Loss of local knowledge on rice } \\
\text { conservation, loss of local rice } \\
\text { varieties, buy rice seeds from } \\
\text { market, low resilience on lack of } \\
\text { rice seeds in the rural area }\end{array}$ \\
\hline & $\begin{array}{l}\text { Soaked rice seeds } \\
\text { in a large basin }\end{array}$ & Large basin & No & Yes & No longer practiced & Los of local knowledge \\
\hline & $\begin{array}{l}\text { Soaked rice seeds } \\
\text { in a fish pond }\end{array}$ & No tools & Yes & No & No longer practiced & Loss of local knowledge \\
\hline \multirow[t]{3}{*}{$\begin{array}{l}\text { Land } \\
\text { preparation } \\
\text { in the rice } \\
\text { field for } \\
\text { rice } \\
\text { seedling }\end{array}$} & $\begin{array}{l}\text { Hoeing and } \\
\text { leveling ground }\end{array}$ & Hoe & Yes & No & No longer practiced & $\begin{array}{l}\text { The seedling nursery is } \\
\text { predominantly made in dryland } \\
\text { (tegal), need to carry and supply } \\
\text { water from water sources when } \\
\text { water is insufficient in the dry } \\
\text { season }\end{array}$ \\
\hline & $\begin{array}{l}\text { Spreading rice } \\
\text { seeds in seedling } \\
\text { place }\end{array}$ & $\begin{array}{l}\text { Bamboo } \\
\text { basket }\end{array}$ & Yes & No & No longer practiced & Loss of local knowledge \\
\hline & Water control & No tools & Yes & No & & Loss of local knowledge \\
\hline \multirow[t]{5}{*}{$\begin{array}{l}\text { Land } \\
\text { preparation } \\
\text { in the rice } \\
\text { field }\end{array}$} & Observation of star & No tools & Yes & Yes & No longer practiced & $\begin{array}{l}\text { Loss of local knowledge on } \\
\text { weather and climatic condition, } \\
\text { and low resilience on the dramatic } \\
\text { change of climatic conditions, } \\
\text { including prolonged drought }\end{array}$ \\
\hline & $\begin{array}{l}\text { Repairing waterway } \\
\text { and repairing dikes }\end{array}$ & Hoe & Yes & No & No change & \\
\hline & $\begin{array}{l}\text { First hoeing and/or } \\
\text { plowing }\end{array}$ & $\begin{array}{l}\text { Hoe, Plough, } \\
\text { Buffalo, Cow }\end{array}$ & Yes & No & $\begin{array}{l}\text { Predominant of hand } \\
\text { tractor }\end{array}$ & $\begin{array}{l}\text { Loss of local knowledge, loss of } \\
\text { buffalo and cow, need fossil } \\
\text { energy from outside of the rural } \\
\text { area }\end{array}$ \\
\hline & $\begin{array}{l}\text { Second hoeing } \\
\text { and/or harrowing }\end{array}$ & $\begin{array}{l}\text { Hoe, Harrow, } \\
\text { Buffalo, Cow }\end{array}$ & Yes & No & $\begin{array}{l}\text { Predominant of hand } \\
\text { tractor }\end{array}$ & $\begin{array}{l}\text { Loss of local knowledge, loss of } \\
\text { buffalo and cow, need fossil } \\
\text { energy from outside of the rural } \\
\text { area }\end{array}$ \\
\hline & Leveling ground & Board slab & Yes & No & No change & \\
\hline \multirow[t]{4}{*}{ Planting } & $\begin{array}{l}\text { Preparing } \\
\text { 'pupuhunan' }\end{array}$ & $\begin{array}{l}\text { Bamboo, } \\
\text { wood, arenga } \\
\text { leaves, } \\
\text { bingbin, seel, } \\
\text { hanjuang }\end{array}$ & Yes & No & No longer practiced & $\begin{array}{l}\text { Loss of local knowledge, less } \\
\text { respects on environmental } \\
\text { conditions }\end{array}$ \\
\hline & $\begin{array}{l}\text { Pull the rice seeds } \\
\text { (babut) }\end{array}$ & No tools & No & Yes & $\begin{array}{l}\text { Undertaken in the } \\
\text { dryland }\end{array}$ & \\
\hline & $\begin{array}{l}\text { Transporting rice } \\
\text { seed bundle from } \\
\text { the seedling nurery }\end{array}$ & No tools & Yes & No & $\begin{array}{l}\text { Transporting from } \\
\text { seedling nursery in } \\
\text { the dryland to wet } \\
\text { rice field plots }\end{array}$ & Carrying seeds a further distance \\
\hline & $\begin{array}{l}\text { Making a line on } \\
\text { the planting filed } \\
\text { for planting rice } \\
\text { (nyaplak) }\end{array}$ & $\begin{array}{l}\text { Comb wood } \\
\text { and bamboo } \\
\text { handle }\end{array}$ & Yes & No & $\begin{array}{l}\text { More predominantely } \\
\text { undertaken }\end{array}$ & $\begin{array}{l}\text { Rice is planted more regularly in a } \\
\text { row }\end{array}$ \\
\hline \multirow[t]{2}{*}{ Maintaining } & $\begin{array}{l}\text { First and second } \\
\text { weeding }\end{array}$ & No tools & Yes & No & No change & \\
\hline & Providing fertilizers & Bamboo & Yes & No & No longer use of & Loss of local knowledge on \\
\hline
\end{tabular}




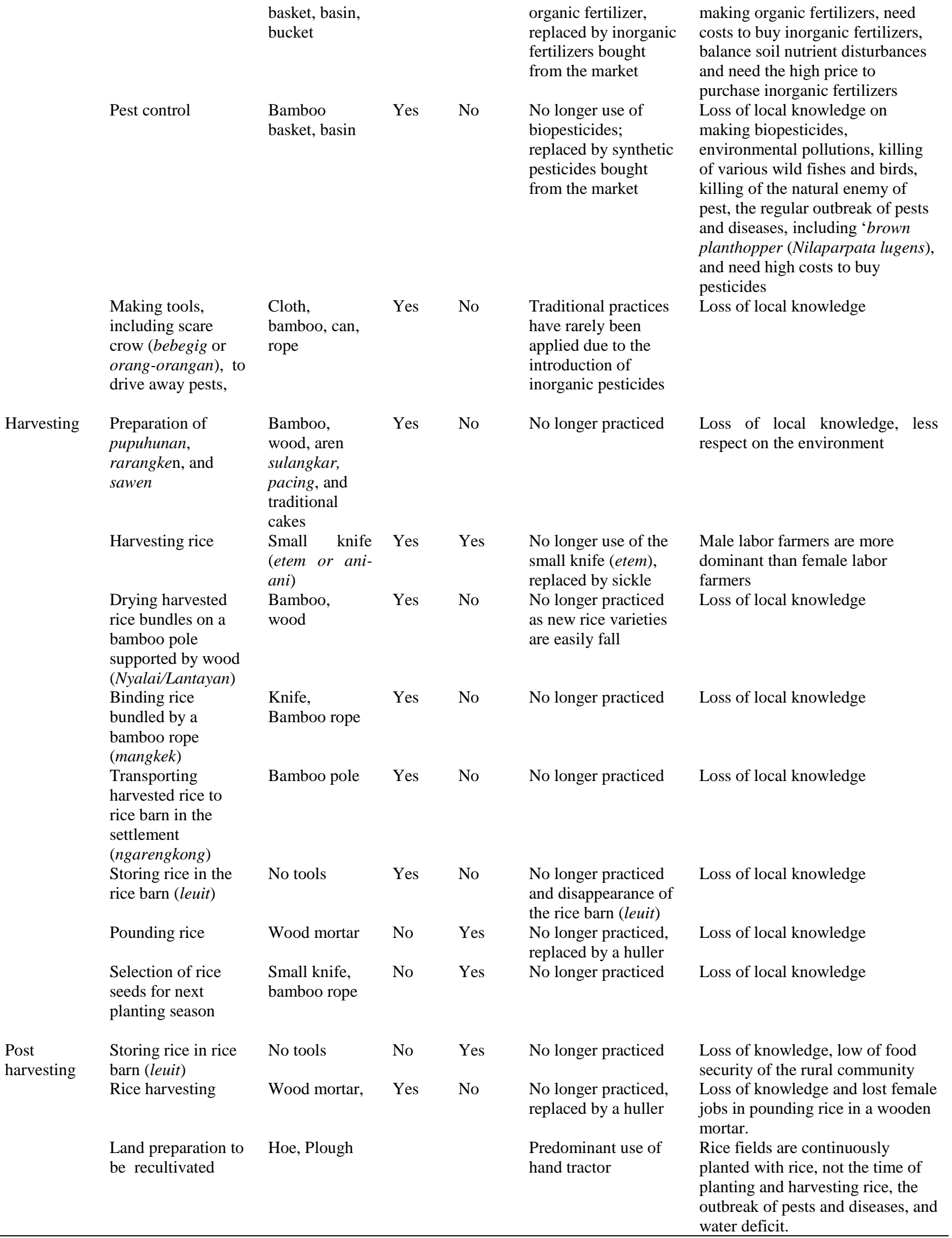


Some local knowledge of female on the constellation of bintang kidang has been lost as the knowledge has not been used since long time ago. Besides, the local knowledge of female farmers on rice seed selection and genetic rice preservation has also been lost since the rice seeds are mainly bought from the market (Table 3). Introduction of new rice varieties has dramatically replaced the local rice varieties as important genetic materials for future rice breeding program to get new superior rice varieties more adaptable to the unpredictable environmental changes, including regular climatic anomaly. Today, by intensively emphasizing the monoculture system of the new rice varieties and intensive use of pesticides, the wet rice farming has been in low resilience in facing various environmental changes, including outbreak of pests such as brown plant hoper/wereng coklat (Nilaparpata lugens) and climate anomaly (Winarto 2016; Iskandar et al. 2018).

Indeed, today, the perception of people on environment and the local natural resource have dramatically changed because they adopted the high external inputs, including high yielding rice varieties, inorganic fertilizers, and synthetic pesticides based on market economic systems. In other words, the genetic diversities of rice crops have dramatically reduced or lost due to cultural changes of farmers as well as ecosystem changes (cf. Iskandar 2017; Samuel 2015; Iskandar et al. 2018). In addition, fundamental changes in social, political, and economic systems at both local and national levels have had profound effects on how rural people use their natural resource base (Dove et al. 2005).

To conlcude, the wet rice cultivation of Karangwangi in the past was traditionally run based on the local knowledge and embedded with local cultures, including traditional beliefs. Various activities of each stage of the wet rice farming were undertaken by male and female farmers based on gender and strongly embeded in the local culture. Unlike male farmers, female farmers have intensively involved in almost every stage of wet rice farming activities. By introduction of the Green Revolution, the female farmers have still engaged in various activities of the wet rice farming. However, some female activities, including observation of star in the sky and rice seed selection have been lost due to the introduction of the Green Revolution.

\section{ACKNOWLEDGEMENTS}

This research was financially supported by the Academic Leadership Grant (ALG) of Professor Johan Iskandar. We thank to Rector of Padjadjaran University who has supported the ALG program. We also would like to thank the head of village leader and his staff and some informants of Karangwangi Village, Cidaun Sub-District, Cianjur District who kindly assisted the researchers by providing various information of this research.

\section{REFERENCES}

Atem. 2018. Gender Relation and Role of Female in Swidden Agriculture. [Thesis]. Postgraduate Program, Universitas Padjadjaran Bandung [Indonesian].

Conway GR. 1986. Agroecosystem analysis for research and development. Winrock International. Bangkok, Thailand.

Cotton CM. 1996. Ethnobotany: principles and applications. John Willey and Sons.Ltd, England.

Creswell JW. 1994. Research design: qualitative and quantitative approaches. Sage Publications, London.

Cunningham AB. 2001. Applied ethnobotany: people, world plant use and conservation. Earthscan Publication, London.

Dove MR. 2005. Use of global legal mechanism to conserve local biogenetic resources: problems and prospects. In Dove MR, Sajise PE, Doolitle AA. (eds), Conserving nature in culture: case studies from Southeast Asia. Yale University Southeast Asian Studies, New Haven, Connecticut.

Dove MR, Sajise PE, Doolittle AA. 2005. Introduction: the problem of conserving nature in cultural landscapes. In Dove MR, Sajise PE, Doolitle AA. (eds), Conserving Nature in Culture: Case Studies from Southeast Asia. Yale University Southeast Asian Studies, New Haven, Connecticut.

Fox JJ. 1991. Managing the ecology of rice production in Indonesia. In Hardjono J. (ed), Indonesia: Resources, Ecology, and Environment. Oxford University Press, Oxford New York.

Herwantiyoko, Katuuk NF. 1997. Basic social knowledge. Gunadarma, Jakarta [Indonesian].

Hutajulu J. 2015. Analysis of role of female in agriculture in Rasau Jaya Sub-District.

Igarashi T. 1985. Some notes on the subsistence in a Sundanese village. In Suzuki S, Soemarwoto O, Igarashi T. (eds), Human Ecological Survey in Rural West Java in 1978 to 1982. Nissan Science Foundation, Tokyo.

Iskandar J. 1998. Swidden Cultivation as a Form of Cultural Identity: the Baduy Case. [Dissertation]. Department of Anthropology, University of Kent at Canterbury, UK.

Iskandar J. 2014. Human and environment and various changes. Yogyakarta: Graha Ilmu (Indonesian).

Iskandar J. 2017. Human ecology and sustainable development. Study Program of Master on Environmental Science, Padjadjaran University, Bandung. Revised Edition [Indonesian].

Iskandar J. 2018. Ethnobiology, ethnoecology, and sustainable development. Plantaxia, Yogyakarta [Indonesian].

Iskandar J, Iskandar BS. 2011. Agroecosystem of Sundanese people. Buku Kiblat Utama Press, Bandung. [Indonesian].

Iskandar J, Iskandar BS. 2016a. Ethnoastronomy the Baduy agricultural calendar and prediction of environtmental perturbation. Biodiversitas 17 (2): 694-703.

Iskandar J, Iskandar BS. 2016b. Plant architectures: structure of village homegarden and urban green open space. Yogyakarta: Teknosain (Indonesian).

Iskandar J, Iskandar BS. 2017. Various plants of traditional rituals: ethnobotanical research among the Baduy community. Biosaitifica 9 (1): 114-125.

Iskandar J, BS Iskandar, R Partasasmita. 2016. Responses to environmental and social-economic changes in the Karangwangi traditional agroforestry, South Cianjur, West Java. Biodiversitas 17 (1): 332-341.

Iskandar J, Iskandar BS, Pratasasmita R. 2018. Review: the impact of social and economic Change on domesticated plant diversity with special reference to wet rice field and homegarden farming of West Java, Indonesia. Biodiversitas 19 (2): 502-514.

Karangwangi village. 2018. Village statistic of Karangwangi in 2018. Local Gov't Cianjur, West Java.

Lansing JS. 1991. Priests and programmers: technologies of power in the pngineered landscape of Bali. Princeton, New Jersey: Princeton University Press, Princeton.

Lovelace GW. 1984. Cultural beliefs and the management of agroecosystems. In Rambo AT, Sajise PE. (eds), An Introduction to Human Ecology Research on Agricultural Systems in Southeast Asia. East-West Center, Hawaii. 
Mahanani S. 2003. Keadilan Agraria bagi Perempuan Petani dalam Konteks Perempuan Petani dan Pengaturan Sumber Agraria (Tanah). Jurnal Wacana 8(2). 1-12.

Martin GJ. 1995. Ethnobotany: a Mmthods manual. WWF International and Chapman \& Hall, London.

Mubyarto. 1989. Introduction to agricultural economics. LP3S, Jakarta [Indonesian].

Reijntjes C, Haverkort B, Waters-Bayer. 1992. Farming for the future: an introduction to low-external-input and sustainable agriculture. The MacMillan Press Ltd, London and Basingstoke

Samuel J. 2015. Biodiversity of food species of the Solanaceae family: a preliminary taxonomic inventory of subfamily Solanoideae. Resources 4: 277-322; doi.10.3390/resources4020277.

Saptari R, Holzner B. 1997. Female working and social change. Pustaka Utami Grafiti, Jakarta [Indonesian].
Seleti YN, Tihompho G. 2014. Rural women subsistence farmers, indigenous knowledge systems and agricultural research in South Africa. J Human Ecol 48: 33-41

Simatauw W. 2001. Gender and natural resource management: an analysis guide. Yayasan Pikul, Kupang [Indonesian].

Spradley JP. 2007. Ethnography method. Tiara Wacana, Yogyakarta [Indonesian].

IFAD. 2009.Gender in agriculture sourcebook. The World Bank, New York.

LPTP. 2010. Agenda of women in the peasant women. Muwazah 2: 205 214.

Winarto YT. 2016. Food crisis and perverted thought: why still continue?. Yayasan Pustaka Obor Indonesia, Jakarta [Indonesian]

Wiramihardja SD. 2013. Ethnoastronomy: the Sundanese of West Java and their relation to ethnoastronomy. News Letter of Center for Southeast Asian Studies (CEAS), Kyoto University, Kyoto. 